\section{Kastamonu Eğitim Dergisi Kastamonu Education Journal}

Mayıs 2019 Cilt:27 Sayı:3

kefdergi.kastamonu.edu.tr
Başvuru Tarihi/Received: 19.02.2018

Kabul Tarihi/Accepted: 06.06.2018

DOI: 10.24106/kefdergi.2724

\title{
Kavram Haritalarının Genel Biyoloji Dersine Yönelik Tutum ve Akademik Başarıya Etkisi ${ }^{1}$
}

\section{Concept Maps for The General Biology Course on The Effects of Academic Achievement and Attitude}

\section{Öz}

\author{
Bilgi Başak GÖKÇEN ÖZGÜN² , Fehime Sevil YALÇIN
}

Bu çalışmanın amacı, genel biyoloji dersinde kavram haritalama ve geleneksel öğretim yöntemlerini kullanmanın öğretmen adaylarının akademik başarısı ve biyoloji dersine yönelik tutumları üzerindeki etkilerini incelemektir. Araştırma Çanakkale Onsekiz Mart Üniversitesi Eğitim Fakültesi Fen Bilgisi Öğretmenliği 2.sınıfta öğrenim gören 103 öğretmen adayının katılımıyla gerçekleştirilmiştir. Araştırmada ön test-son test kontrol gruplu deneysel araştırma modeli kullanıımıştır. Veri toplama aracı olarak Genel Biyoloji Dersi Akademik Başarı Testi ve Biyoloji Dersine Yönelik Tutum Ölçeği kullanılmıştr. Araştırma sonucunda; deney ve kontrol grubundaki öğrencilerin akademik başarı ve tutum son testlerinden aldıkları puanlar arasında anlamlı bir fark tespit edilememiştir ( $p>.05)$. Deney ve kontrol gruplarının akademik başarı ve tutum ön test/son test karşılaştırmalarına göre hem kavram haritalama ile hem de geleneksel öğretim yöntemi ile ders alan öğrencilerin başarı ve tutumlarında son test lehine anlamlı farklılıklar tespit edilmiştir $(\mathrm{p}<.05)$.

\section{Anahtar Kelimeler: akademik başarı, kavram haritalama, öğretmen adayları, tutum}

\section{Abstract}

The purpose of this study, examine the impact of using conceptual mapping and traditional teaching methods on preservice teachers' academic achievement and attitudes towards biology lessons in the general biology course. The research was carried out with the participation of 103 preservice teachers who were educated in the second grade of the Canakkale Onsekiz Mart University Faculty of Education of Science Education. Experimental research model with pretest-posttest control group was used in the research. The General Biology Course Academic Achievement Test and the Attitude Scale towards Biology Course were used as data collection tools. As a result of the research; there was no significant difference between students' academic achievement and attitude scores $(p>.05)$. According to the academic achievement and attitude pretest/posttest comparisons of experimental and control groups, significant differences were found in favor of the posttest in the achievement and attitudes of the students taking the course with both concept mapping and traditional teaching method $(p<.05)$.

Keywords: academic achievement, concept mapping, pre-service teacher, attitude

1. Bu araştrrma Çanakkale Onsekiz Mart Üniversitesi Bilimsel Araştırma Projeleri Birimi tarafindan 2010/116 No'lu proje ile desteklenen Yüksek Lisans Tezinin bir bölümüdür. Ayrıca çalışmanın bir kısmı 3rd Edition of The International Conference New Perspectives in Science Education (20-21 Mart 2014, Florence, Italy)'da poster olarak sunulmuştur.

2. İnönü Üniversitesi, Eğitim Bilimleri Enstitüsü, Fen Bilgisi Eğitimi Bilim Dalı, Malatya, Türkiye; https://orcid.org/0000-0001-7955-0897

3. Çanakkale Onsekiz Mart Üniversitesi, Eğitim Fakültesi, Matematik ve Fen Bilimleri Eğitimi Bölümü, Biyoloji Eğitimi, Çanakkale, Türkiye; https://orcid.org/00000003-0661-6431

Atıf / Citation: Gökçen Özgün, B.B., ve Yalçın, F.S. (2019). Kavram haritalarının genel biyoloji dersine yönelik tutum ve akademik başarıya etkisi.Kastamonu Education Journal, 27(3), 1149-1162. doi:10.24106/kefdergi.2724 


\section{Extended Summary}

Education is one of the most important problems of our country in the 21st century. For many years the perception of memorizing education has been prevented from reaching the desired level of education. constructivist learning approach in Turkey since 2004, according to this approach is very much based on the methods and techniques have been developed. (Çömek, Akınoğlu, Elmacı \& Gündoğdu, 2016). Novak, Gowin \& Johansen (1983) stated that "concept mapping" is one of the effective learning techniques in meaningful learning.

Concept maps in literature; success (Akbaş \& Toros, 2016; Çömek et al., 2016; Erdoğan, 2016), attitude (Akay et al., 2012; Polat \& Doğan, 2015), the detection and correction of misconceptions (Aykutlu \& Şen, 2012; Bayram \& Ersoy, 2014), meaningful learning provision (Novak, Gowin \& Johansen 1983; Kaptan, 1998), increasing the retention of knowledge (Novak \& Gowin, 1984; Sarıca \& Çetin, 2012) investigated the effects on learning products as it is situated numerous studies.

Despite the fact that there are many studies to test the effectiveness of concept maps in biology in science education (Esiolu \& Soyibo, 1995; Binzat, 2000; Çimer \& Çimer, 2002; Doğru, 2002; Gürlek, 2002; Çağlayan, 2006), it can be said that the work carried out in this subject is limited. The researches supported by the concept maps in the biology lessons in which the concepts at the university level are concentrated especially are limited. It is thought that the conclusions of this study, which we have made in order to demonstrate the effects of concept mapping on the attitudes and academic achievements of the science teacher candidates towards the general biology lesson, will contribute to the work to be done in this subject.

In this study, it is aimed to investigate the effects of the use of concept maps in the general biology lessons of science teacher candidates on attitude and academic achievement towards general biology lesson and the difficulties encountered in learning process.

A sample of the research using the experimental design with the pre-test and post-test group-a total of 103 teacher candidates studying in the second grade of the Canakkale Onsekiz Mart University Faculty of Education of Science Education. In this research, data were collected by Academic Achievement Test for General Biology Course developed by researchers and Attitude Scale towards Biology Course developed by Pehlivan \& Köseoğlu (2010). The analysis of the data was made in the SPSS 17 Package Program.

As a result of the research, it was determined that there was no statistically significant difference between the test results of the experimental and control groups according to the academic achievement test results applied after the experimental study. Teaching has also been successful with concept maps used in this research. It has been understood that the learning outcomes achieved using concept maps are slightly higher than the teaching method used in the traditional method, but there is no significant difference between them. On this result, it can be said that the readiness levels of the teacher candidates in both groups are influential. Various researchers give information about the effect of success in teaching with concept maps. There was a similarity between these research results and the results obtained by different researchers in the literature review (Kulaberoğlu \& Gürdal, 2001; Çimer \& Çimer, 2002; Ekmekçioğlu, 2007; Erdoğan, 2007; Akay, 2010). There are also studies that show that concept mapping does not always affect success in a positive way (Bou-Jaoude \& Attich, 2008; Lin, Chang, Hou \& Wu, 2015; Snead \& Young, 2003; Akt. Çömek et al, 2016).

The study also investigated the impact of the use of concept maps in biology lessons on students' biology lessons. After the study, the attitude pre-test post-test comparisons of the experimental and control groups were statistically different in favor of the post-test $(p<.05)$. According to this result, it was concluded that the use of concept map at the end of the 10-week period had a significant effect on the attitudes of the prospective teachers to the biology lesson. However, the final test results of the experimental and control groups are not different. From this, it can be said that both conventional and concept mapping methods are effective at the same level. The findings obtained from the research are in parallel with the findings obtained from the studies about the attitude (Ekmekçioğlu, 2007; Akay, 2010).

As a result, it has been stated that concept maps may be inadequate when used alone as a teaching strategy, and that it is the most successful when applied together with other classroom activities (Kinchin, 2000, Akgündüz \& Bal, 2013).

Depending on the results obtained from this study, the following suggestions can be made; Key concepts must be selected correctly before the concept map is made, enough time should be allocated for concept map training and construction. Computer-aided concept maps can be used to make concepts easier to insert in the drawing of concept maps. One of the most important points to note in concept maps is to create maps that are appropriate for language rules. Concept maps are an appropriate educational tool for different levels of teaching and should be used by teachers and students in teaching and learning environments as a learning, teaching and evaluation tool.

| Kastamonu Eğitim Dergisi, 27(3), 2019| 


\section{Giriş}

Eğitim, 21.yüzyılda Türkiye'nin en önemli sorunlarından biridir. Uzun yıllar uygulanan ezbere dayalı eğitim anlayışı, eğitim seviyesinin istenen düzeye çıkmasını engellemiştir. Bu duruma çözüm aranması amacıyla bilginin nasıl yapılandırılabileceği, nasıl kalıcı olabileceği ve günlük hayata nasıl aktarılabileceği ile ilgili pek çok araştırma yapılmıştr. Türkiye'de 2004 yılından itibaren uluslararası sınav değerlendirmelerinden ve sosyal, politik, bilimsel, ekonomik gerekçelerle ilköğretim ve ortaöğretim programları yapılandırmacı öğrenme yaklaşımı esas alınarak yeniden ele alınmıştır (Çömek, Akınoğlu, Elmacı ve Gündoğdu, 2016). Soyut ve karmaşık kavramlar içeren fen derslerinde ezbere eğitimin yerine anlamlı öğrenmenin sağlanabilmesi için yapılandırmacı yaklaşıma uygun olarak pek çok yöntem ve teknik geliştirilmiştir. Novak, Gowin ve Johansen (1983) anlamlı öğrenmeyi sağlamada "kavram haritalama"nın etkili öğrenme tekniklerinden biri olduğunu belirtmişlerdir.

Kavram haritaları tek bir kavramın aynı kategorideki diğer kavramlarla ilişkisini gösteren somut grafiklerdir (Kaptan, 1998). Bilişsel yapıdaki değişmeleri incelemeye yarayan kavram haritaları stratejisi ilk kez Novak ve Cornell Üniversitesi mezunu öğrenciler tarafindan 1970'li yıllarda Ausubel (1968)'in "Anlamlı Öğrenme" kuramından yola çıkılarak geliştirilmiştir. Novak ve Gowin (1984)'e göre en genel kavram haritanın en tepesinde, daha az içerikli ve özel kavramlar alt sıralarda yer almalı, böylece hiyerarşik düzen sağlanmaya çalışılmalıdır. Alan yazında kavram haritalarının çeşitli türlerinden bahsedilmektedir. Taricani (2002) kavram haritalarını dörde ayırmıştır:

1. Belli bir kavram ya da ana fikirle ilgili kavram ve düşüncelerin gösterimini sağlayan örümcek kavram haritaları

2. Belli bir sürecin, işlemin aşamalarını gösteren akış diyagramları

3. Bir sistemin işleyişini, girdi çıkt ilişkisini ortaya koyan sistem kavram haritaları

4. Bilginin yapısını hiyerarşik olarak ve kavramlar arası ilişkileri gösterecek şekilde ortaya koyan hiyerarşik kavram haritalarıdır.

Novak ve Gowin (1984)'e göre kavram haritalarının üç temel özelliği vardır. Bunlar; anahtar kavramlar, önermeler ve çapraz bağlantılardır. Bir kavram haritası, bu temel gerekliliklerin tümünü kapsamalıdır (Şimşek, 2006). Novak (2002) kendi geliştirdiği kavram haritalarının diğerlerinden farkını şu şekilde ortaya koymuştur:

"Alan yazında pek çok farklı "kavram haritası" belirmesine karşın, bizim takımımızın geliştirdiği bilgi ifade aracı, kavramları ve hiyerarşik bir yapı oluşturma amacıyla açık önermeleri göstermektedir. Kutucuklar arasındaki bağlantları kesin olarak belirtmeyen diğer kavram haritaları bizim anlamı ifade etmede temel öğe olarak kabul ettiğimiz önermelerin yapılandırılmasında başarısız olur. Hiyerarşinin olmaması ise bilgi yapısına eklenecek bağlamda hangi kavramın daha önemli ya da kapsamlı olduğunu belirtmekte başarısızlığa neden olur." (Novak, 2002; Akt. Altınok, 2004).

Bu çalışmada adı geçen "kavram haritaları" ifadesi Novak ve diğ. (1983) tarafindan geliştirilen "hiyerarşik kavram haritaları" veya "Novak stili kavram haritaları" olarak ifade edilerek diğerlerinden ayrılan kavram haritaları için kullanılmıştr. Çalışmada kullanılan kavram haritaları, Novak'ın geliştirmiş olduğu hiyerarşik kavram haritalarıdır.

Literatürde kavram haritalarının; başarı (Akbaş ve Toros, 2016; Çömek ve diğ., 2016; Erdoğan, 2016), tutum (Akay ve diğ., 2012; Polat ve Doğan, 2015), kavram yanılgılarının tespiti ve düzeltilmesi (Aykutlu ve Şen, 2012; Bayram ve Ersoy, 2014), anlamlı öğrenmeyi sağlama (Novak, Gowin ve Johansen 1983; Kaptan, 1998), bilginin kalıcılığını arttırma (Novak ve Gowin, 1984; Sarıca ve Çetin, 2012) gibi öğrenme ürünleri üzerindeki etkilerini araştıran çok sayıda çalışma yer almaktadır.

Kavram haritalarının karakterinin (hiyerarşik kavramlarının fazla oluşu sebebiyle) fen bilimlerine daha yatkın olması bu alandaki kullanımını arttırmıştır (Günhan, 2009). Literatürde fen eğitiminde yer alan fizik (Açar, 2007; Evrekli ve diğ, 2009), kimya (Erdem, 2008; Bayram ve Ersoy, 2014; Yavuz ve Büyükekşi, 2015) ve biyoloji (Aykanat ve diğ, 2005; Güneş, Güneş ve Çelikler, 2006; Çetinkaya ve Taş, 2011; Kasapoğlu, 2011) konularında yapılmış çeşitli çalışmalara rastlamak mümkündür. Fen eğitiminde önemli öğrenme araçlarından biri olduğu için kavram haritaları ile çalışmalar yapılmaya devam etmektedir.

Fen eğitimi ile hedeflenen amaçların gerçekleştirilebilmesinin, soyut ve karmaşık olan fen konularının anlaşılırlığının artırılmasına, etkili yöntem ve tekniklerin kullanılmasına bağlı olduğu bilinmektedir. Kavram haritalarının fen eğitiminde yer alan biyoloji konularındaki etkililiğini test etmek üzere yapılmış pek çok çalışma (Esiolu ve Soyibo, 1995; Binzat, 2000; Çimer ve Çimer, 2002; Doğru, 2002; Gürlek, 2002; Çağlayan, 2006) olmasına rağmen, bu konuda yürütülen çalışmaların sınırlı sayıda olduğu söylenebilir. Özellikle üniversite düzeyinde kavramların yoğun olduğu biyoloji derslerinde öğretimin kavram haritalarıyla desteklendiği araştırmalar sınırlı sayıdadır. Bu çalışmada kavram haritalamanın fen bilgisi 
öğretmen adaylarının genel biyoloji dersine yönelik tutum ve akademik başarıları üzerindeki etkisini ortaya koymak amaçlanmıştır.

\section{Araştırmanın Amacı}

Bu çalışmada, fen bilgisi öğretmen adaylarının genel biyoloji derslerinde kavram haritaları kullanımının genel biyoloji dersine yönelik tutum ve akademik başarı üzerine etkisi ve öğrenme sürecinde karşılaşılan zorlukların incelenmesi amaçlanmıştır. Araştırmada aşağıdaki sorulara cevaplar aranmıştır:

1. Deney ve kontrol gruplarına ait başarı ve tutum ön test ortalama puanları arasında anlamlı bir fark var mıdır?

2. Deney ve kontrol gruplarının akademik başarı son test ortalama puanları arasında anlamlı bir fark var mıdır?

3. Deney ve kontrol grubunun akademik başarı ön test-son test puanları arasında anlamlı bir fark var mıdır?

4. Deney ve kontrol gruplarının tutum son test ortalama puanları arasında anlamlı bir fark var mıdır?

5. Deney ve kontrol grubunun tutum ön test-son test puanları arasında anlamlı bir fark var mıdır?

\section{Yöntem}

Ön test-son test kontrol gruplu deneysel desenin kullanıldığı araştırmanın örneklemini Çanakkale Onsekiz Mart Üniversitesi Eğitim Fakültesi Fen Bilgisi Öğretmenliği 2.sınıfta öğrenim gören toplam 103 öğretmen adayı oluşturmaktadır.

Tablo 1. Deneklerin Gruplarına ve Cinsiyetlerine Göre Dağııımı

\begin{tabular}{lcccccc}
\hline \multirow{2}{*}{ Cinsiyet } & \multicolumn{2}{c}{ Deney Grubu } & \multicolumn{2}{c}{ Kontrol Grubu } & \multicolumn{2}{c}{ Toplam } \\
\cline { 2 - 7 } & $\mathrm{N}$ & $\%$ & $\mathrm{~N}$ & $\%$ & $\mathrm{~N}$ & $\%$ \\
\hline Kız & 46 & 44,6 & 35 & 34 & 81 & 78,6 \\
Erkek & 8 & 7,8 & 14 & 13,5 & 22 & 21,3 \\
Toplam & 54 & 52,4 & 49 & 47,5 & 103 & 100 \\
\hline
\end{tabular}

\section{Veri Toplama Araçları}

Bu araştırmada veriler araştrmacılar tarafindan geliştirilen Genel Biyoloji Dersine Yönelik Akademik Başarı Testi ve Pehlivan ve Köseoğlu (2010) tarafindan geliştirilen Biyoloji Dersine Yönelik Tutum Ölçeği ile toplanmıştır.

\section{Genel Biyoloji Dersi Akademik Başarı Testi}

Araştırmacı tarafindan geliştirilen Genel Biyoloji Dersi Akademik Başarı Testi, Genel Biyoloji II dersi kazanımları dikkate alınarak Fen Bilgisi Öğretmenliği 2.sınıf öğretmen adaylarına ünitelerle ilgili çoktan seçmeli bir test şeklinde hazırlanmıştır. Çalışmada Biyoloji II dersi kapsamında bulunan 9 biyoloji konusu; canlı sistemlerde enerji akışı, oksijenli solunum, bitkilerde büyüme, üreme ve gelişme, hayvanlarda beslenme ve sindirim, hayvanlarda solunum, hayvanlarda dolaşım, hayvanlarda boşaltım, hayvanlarda sinir sistemi ve bitki metabolizması olarak ele alınmıştır.

Kapsam geçerliğinin sağlanması için ayrıca iki biyoloji konu alanı uzmanının ve bir ölçme-değerlendirme uzmanının görüşlerine başvurulmuş ve dil bakımından uygunluğunun belirlenmesi için uzman görüşü alınmıştı. Başlangıçta kazanımlara uygun olarak 50 soruluk çoktan seçmeli test oluşturulmuş ve pilot test uygulaması yapılmıştır. Pilot test uygulama sonrası yapılan madde analizi doğrultusunda ayırtedicilik indisi .30'un altında olan soruların çıkarılmasına karar verilmiştir. Kalan diğer 36 soru için geçerlik ve güvenirlik ölçümleri yapılmıştır. Bu çalışmada güvenirliğin hesaplanmasında Cronbach Alfa katsayısının özel bir hali olan KR-20 formülü kullanılmıştır (Tavşancıl, 2002). Yapılan geçerlik ve güvenirlik hesaplanması sonucu, testin (Cronbach's Alpha değeri 0,816) güvenirlik katsayısı (KR-20) 0.80 olarak bulunmuştur. Testten alınabilecek en düşük puan 0, en yüksek puan 36'dır.

\section{Biyoloji Dersine Yönelik Tutum Ölçeği}

Çalışmada Demirci (2003) tarafindan geliştirilen fen bilgisi dersine yönelik tutum ölçeğinin Pehlivan ve Köseoğlu (2010) tarafindan biyoloji dersine uyarlanmış hali kullanıımıştır. Pehlivan ve Köseoğlu (2010) 32 maddeden oluşan biyoloji dersine yönelik tutum ölçeğinin alfa güvenirlik katsayısını 0.96 olarak bulmuştur. Cevaplar "tamamen katılıyorum (5), Kathlıyorum (4), Kararsızım (3), Katılmıyorum (2), Kesinlikle katılmıyorum (1)" şeklinde ölçeklendirilmiştir. Olumsuz cümleler ise ters kodlanmıştır.

\section{Uygulama}

Bu çalışma toplam 12 hafta (2 hafta ön-son testlerin uygulanması ve kavram haritalama eğitimi) sürmüştür. Uygula- 
malar araştırmacı tarafindan hem deney hem de kontrol grubunda haftada 3'er saat olacak şekilde gerçekleştirilmiştir. Her konunun işlenme süresinin iki grupta da aynı olmasına dikkat edilmiştir. Öğrencilerinin tamamına akademik başarı testi ve biyoloji dersine yönelik tutum testi ön test ve son test olarak uygulanmıştr.

Kontrol grubunda ise geleneksel öğretim uygulanarak, dersler düz anlatımla işlenmiştir. Kavram haritaları uygulamalarının yapıldığı deney grubunda dersler işlendikten sonra öğrencilerden kâğıt kalem kullanarak konu ile ilgili kavram haritaları yapmaları istenmiştir.

\section{Kavram Haritalama Eğitimleri}

Öğrencilerin kavram haritası çizebilmeleri için eğitim almış olmaları şarttır (Kalaycı, 2001; Kaya, 2003b). Çalışmada deney grubuna kavram haritalama metodunun öğretilmesi amacıyla kavram haritalama konusunda uzman görüşü alınarak bir öğretim programı hazırlanmıştır. Geliştirilen program Novak tarafindan önerilen Kavram Haritalama Stratejisinden faydalanılarak yapılmıştır (Novak ve Gowin, 1984; Kaya, 2003a; Kaya, 2003b; Kaya ve Ebenezer, 2003). Öncelikle kavram haritalama öğretim planı taslağı çalışma grubu dışındaki farklı bir gruba uygulanmıştır. Uygulama sonucunda öğretim planının etkililiği uzmanlarca tartışılarak ve eksikleri tamamlanarak deney grubuna uygulanabilir hale getirilmiştir. Daha sonra deney grubundaki 54 öğrenciye 8 saatlik Kavram Haritalama Eğitimi verilmiştir. Öğretmen adaylarına kavram haritası hakkında bilgiler verilerek, hazırlanan plan dâhilinde kavram haritalarının nasıl yapılacağı konusunda çeşitli uygulamalar yaptırılmıştr.

Deney grubuna verilen Kavram Haritalama Eğitimi iki aşamadan oluşmaktadır:

1. Kavram haritası yapmaya hazırık etkinlikleri: Bu etkinliklerde amaç, öğretmen adaylarına kavram haritalarında yer alacak kavramları seçme, bu kavramları genelden özele, anlamca en kapsamlıdan dar kapsamlı olana sıralama becerisi kazandırmaktır.

- Öğretmen adaylarına örneklerden yola çıkılarak olay ve objenin ne olduğu kavratılır.

- Kavram sözcüğü tanımlanır. Kavramların eşyaları, olayları, insanları ve düşüncelere benzerliklerine göre grupladığımızda oluşan bu gruplara verilen ad olduğu belirtilir.

- Özel isimlerin kavram olmadığı açıklanır ve özel isimlere örnekler verilir.

- Cümlelerde yer alan kavramları nasıl tespit edebilecekleri örneklerle anlatılır.

- Cümlelerde kavramların dışında kalan kelimelerin ne anlama geldiği ve görevi açıklanır. Öğrencilere bu kelimelerin bağlant kelimesi olduğu açıklanarak örnekler üzerinde gösterilir.

- Kavramları ve bağlant kelimelerini kullanarak cümle oluşturulma alıştırmaları yapılır.

- Bir okuma parçası dağıttlarak öğrencilerin parçadaki kavramları belirlemeleri istenir.

- Tahtada öğrencilerin belirlediği kavramlardan oluşan bir liste oluşturulur. Parçanın ana fikrinden yola çıkılarak listedeki en önemli kavramlar belirlenir. Kavramların genelden özele en kapsamlıdan dar kapsamlıya doğru sıralamaları yapılır.

- Öğretmen adaylarına yeni bir metin verilerek metinde yer alan kavramları ve bunları genelden özele sıralamaları istenir ve dönütler sağlanarak hazırlık süreci tamamlanır.

2.Kavram haritalama etkinlikleri: Bu etkinlikte öğretmen adaylarına kavram haritası yapabilme becerisi kazandırmak amaçlanmıştır.

- Öğretmen adayları tarafindan geliştirilen listelerden biri kullanılarak bir kavram haritası hazırlanır. Harita yapılırken dikkat edilmesi gereken kurallar açıklanır.

- Yeni bir metin verilerek onlardan kavramları bulmaları istenir ardından kavramlar tahtaya yazılır. Birlikte hiyerarşik bir sıraya konulan birkaç kavramla kavram haritalama etkinliğine başlanır. Harita yarım bırakıır. Öğretmen adaylarının haritayı kağıtlarına kopyalamaları ve tamamlamaları istenir.

- Aynı kavramlarla ilgili en dar kapsamlı olan bir kavram tahtaya yazılır. Öğretmen adaylarının haritayı dar kapsamlıdan geniş kapsamlıya doğru tamamlamaları istenir, yaptıkları haritaların bağlantıları kıyaslanır ve zayıf olan bazı bağlantılar gösterilerek onlardan kavram haritalarını bazı değişikliklerle yeniden kurmaları istenir.

- Yeni bir metin verilerek onlardan kavramları çıkarmaları istenir. Hiyerarşik yapıda orta düzeyde bulunan bir kavram tahtanın ortasına yazılır. Öğretmen adaylarından kavram haritalarını tamamlamaları istenir.

- Öğretmen adaylarına bildikleri bir kavramla ilgili; üzerine kutuları, bazı kavramları ve bağlant cümleleri yazılmış çalışma kağıtları verilerek onlardan boş bırakılan kavramları doldurmaları istenir.

- Öğretmen adaylarına iyi bildikleri bir kavramla ilgili olarak üzerine kavramları yerleştirilmiş ancak ilişki sözcükleri yazılmamış bir harita, çalışma kâğıdı olarak öğrencilere dağıtılarak onlardan ilişki sözcüklerini kendilerinin yerleştirmesi istenir. 
- Bir metin verilerek öğretmen adaylarından kavramları bulmaları, listelemeleri, hiyerarşik sıraya koymaları ve bir harita hazırlamaları istenir.

- Hep birlikte iyi bir kavram haritasında bulunması gereken özellikler tartşılarak eğitim tamamlanır.

Öğretmen adayları tarafindan çizilmiş bazı kavram haritaları şekil 1,2,3 ve 4’ de verilmiştir.

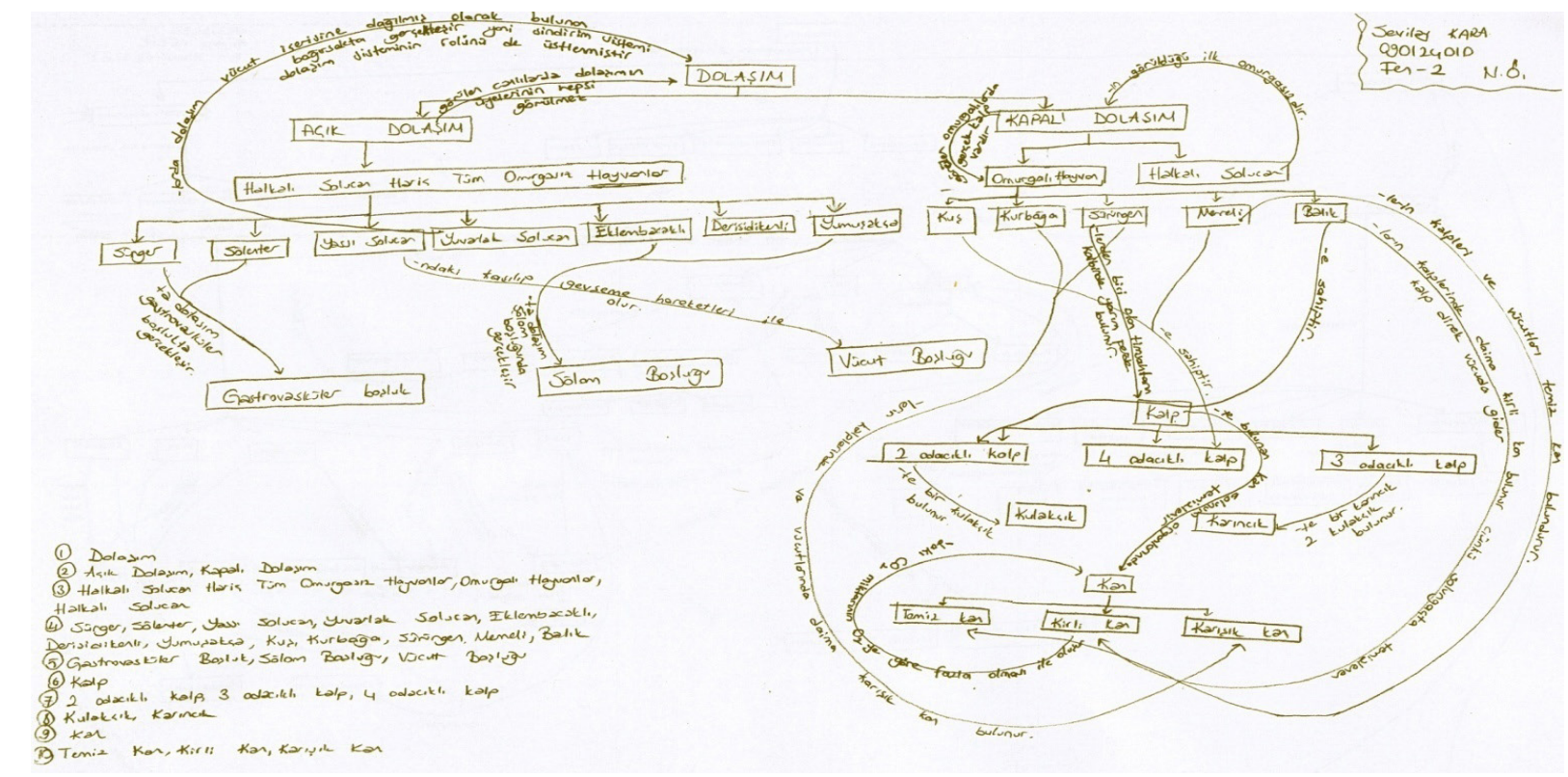

\section{Şekil 1. Dolaşım Sistemi Konusu ile İlgili Öğrenci Kavram Haritası}

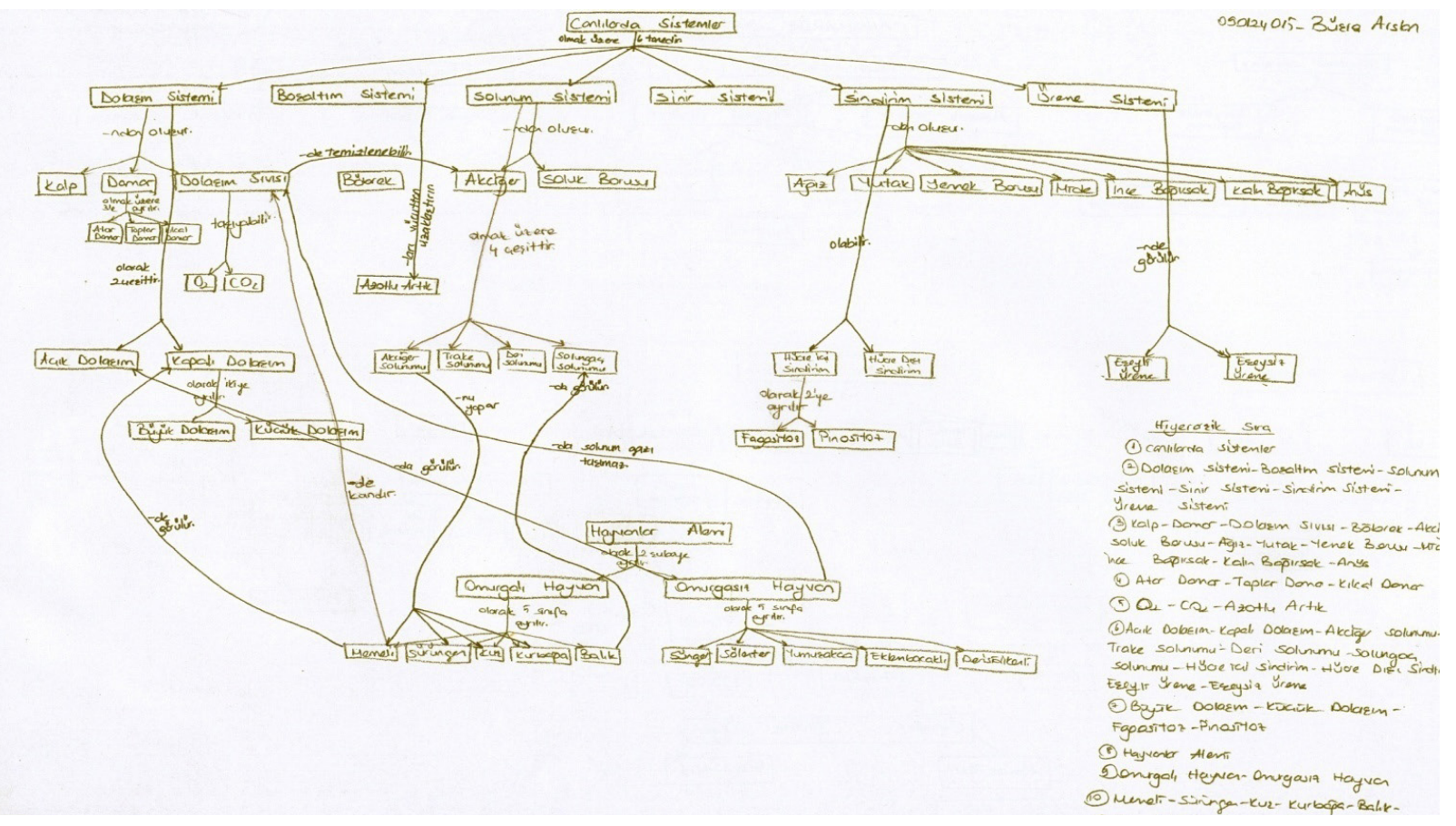

Şekil 2. Canılılarda Sistemler Konusu ile İlgili Öğrenci Kavram Haritası 


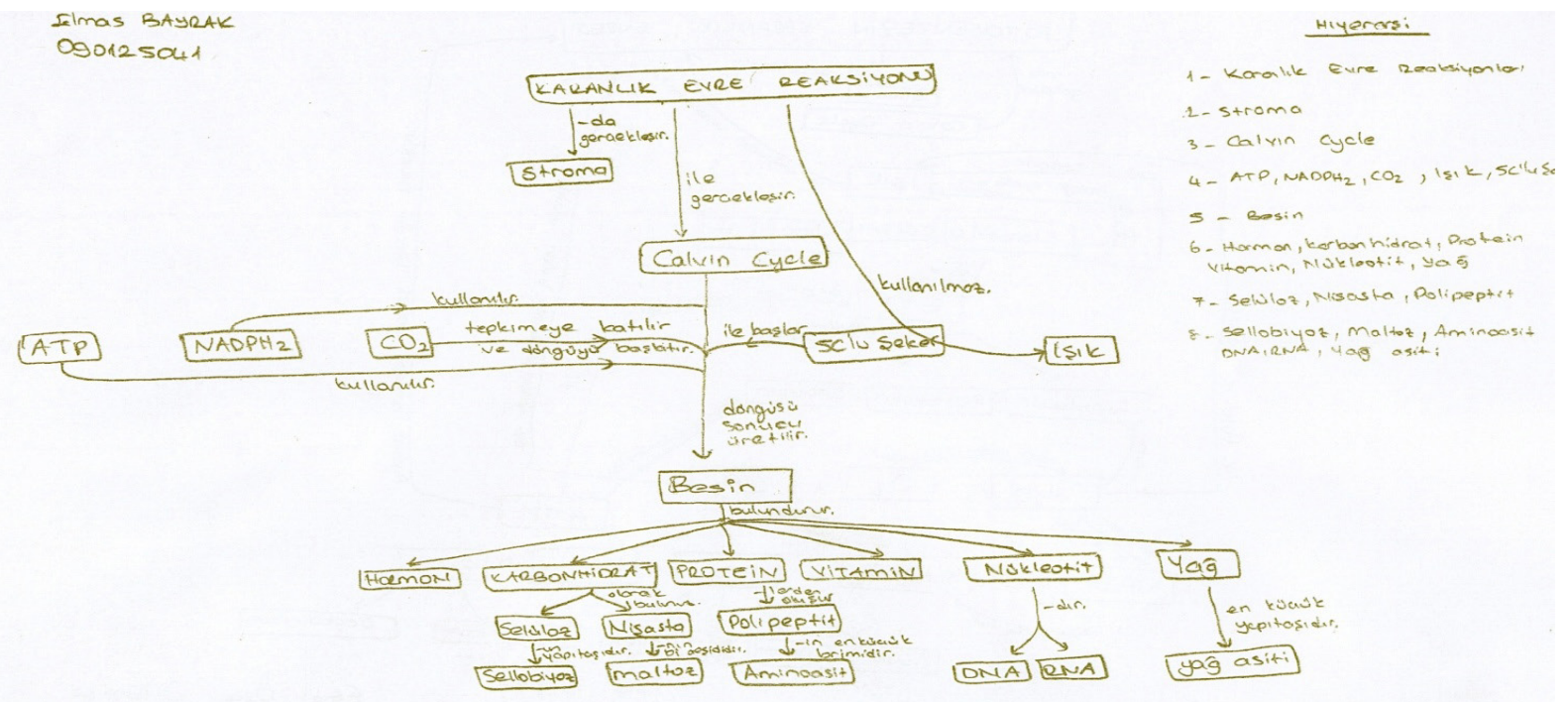

Şekil 3: Fotosentezin Karanlık Evre Reaksiyonları ile İlgili Öğrenci Kavram Haritası

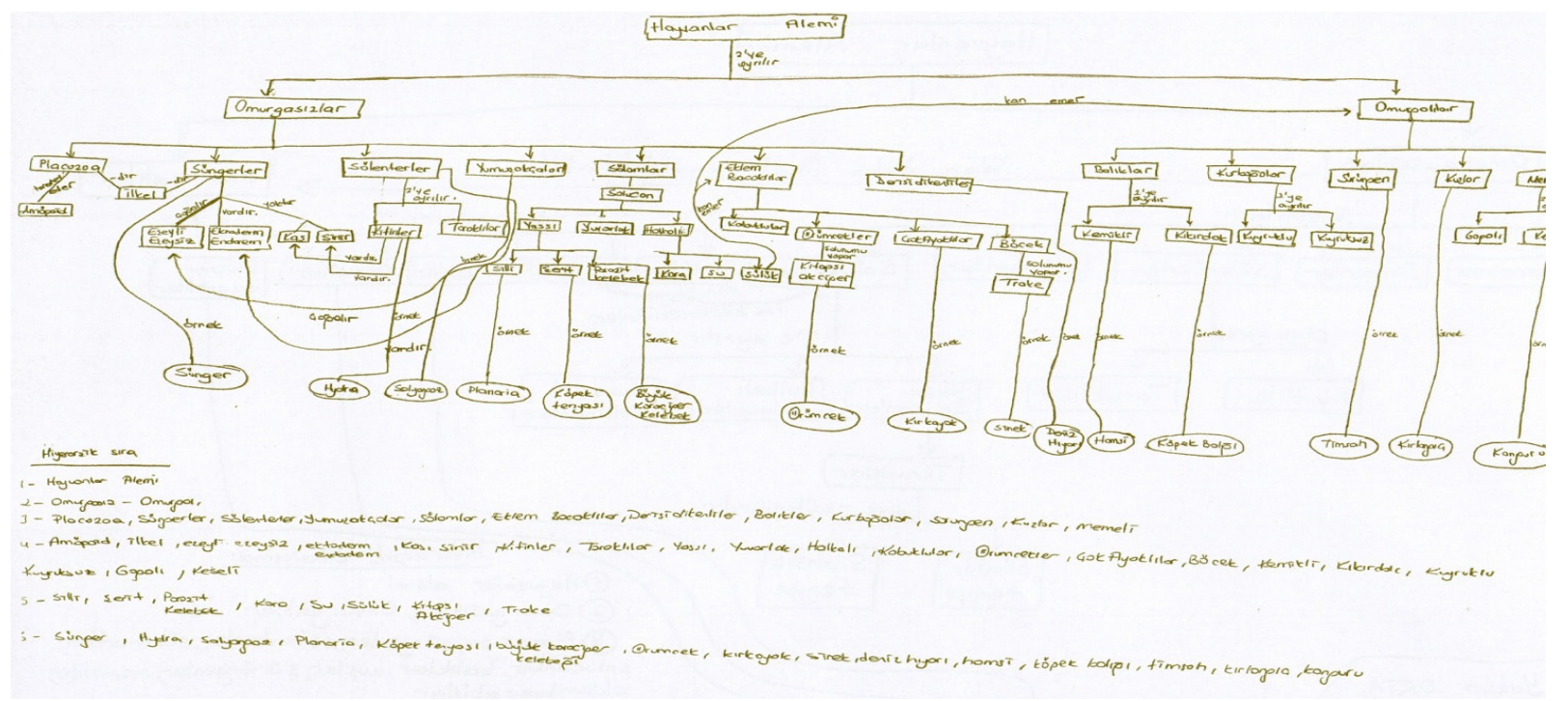

Şekil 4: Hayvanlar Âlemi Konusu ile İlgili Öğrenci Kavram Haritası

\section{Verilerin Analizi}

Öntest ve sontestten elde edilen verilerin analizi SPSS 17 Paket Programı'nda yapılmıştr. Hem kontrol ve deney grupları arasında hem de grupların kendi içlerinde anlamlı bir fark olup olmadığını belirlemek için analiz tekniği olarak t-testi ve ANCOVA kullanılmıştr.

Kovaryans Analizi (ANCOVA) ile bir araştırmada etkisi test edilen bir faktörün ya da faktörlerin dışında, bağımlı değişken ile ilişkisi bulunan bir değişkenin ya da değişkenlerin istatistiksel olarak kontrol edilmesi sağlanır. ANCOVA ön ölçümlerde gruplar arası farkların olduğu durumlarda çalışmadaki yanlıılıkta bir azalma sağlaması ve hata varyansını azaltması nedeniyle büyük bir istatistiksel güç sağlar (Canbolat, 2008). Böylece araştırma deseni ile kontrol altına alınamayan dış etkenler, doğrusal bir regresyon yöntemi ile ortadan kaldırarak deneydeki işlemin gerçek etkisi belirlenmiş olur (Büyüköztürk, 2010). ANCOVA ile bağımlı değişken üzerindeki her bir gözlem için, ortak değişkene dayalı düzeltilmiş değerler üretilir ve bu değerlerden hesaplanan düzeltilmiş grup ortalama puanları arasındaki farkların anlamlı olup olmadığı incelenir (Büyüköztürk, 2010).

Araştırmada bunların yanı sıra "ilişkili örneklemler t-testi” de kullanılmıştr. (Büyüköztürk, 2010)'e göre ilişkili örneklemler t-testi, ilişkili iki örneklemin ortalamaları arasındaki farkın sıfirdan (birbirinden) anlamlı bir şekilde farklı olup olmadığını test etmek için kullanılır. Akademik başarı ve tutum değişkenlerine ait deneysel işlem öncesi ve deneysel işlem sonrası olmak üzere iki farklı zamandaki ölçümlerine ilişkin ortalamalarını karşılaştrarak, söz konusu ortalamalar arasındaki farkın belirli bir güven düzeyinde anlamlı olup olmadığını test etmek için ilişkili ölçümler için t-testi kullanıl- 
mıştir (Ural ve Kılıç, 2005).

\section{Bulgular}

Bu bölümde, araştırma problemi doğrultusunda yapılan çalışmada deney ve kontrol gruplarının ön ve son test verileri tablolar halinde düzenlenmiş ve yapılan istatistiksel analizler sonucunda ulaşılan bulguların yorumları yapılmıştır.

\section{Birinci alt probleme ilişkin bulgular}

Örneklem grubunun çarpıklık ve basıklık katsayılarının $(-1,5 ;+1,5$ aralığı) ve histogram grafiğinin normal dağılıma işaret ettiği (Tabachnick and Fidell, 2013) belirlendikten sonra araştırmada deney ve kontrol gruplarına ait ön test puan ortalamaları arasındaki farklıı̆ı̆ tespiti için bağımsız örneklem $t$ testi uygulanmıştır. Akademik başarı ve tutum ön testlerine ilişkin bağımsız örneklem t testi sonuçları Tablo 2'de verilmiştir.

\section{Tablo 2. Deney ve Kontrol Gruplarının Akademik Başarı ve Tutum Ön test Puanları}

\begin{tabular}{llcccccc}
\hline & & $\mathrm{N}$ & $\overline{\mathrm{X}}$ & $\mathrm{S}$ & $\mathrm{SS}$ & $\mathrm{t}$ & $\mathrm{p}$ \\
\hline \multirow{2}{*}{ Akademik başarı } & Deney & 54 & 21.20 & 4.24 & \multirow{2}{*}{101} & \multirow{2}{*}{1.50} & .136 \\
& Kontrol & 49 & 19.88 & 4.72 & & & \\
\hline \multirow{2}{*}{ Tutum } & Deney & 54 & 129.57 & 19.71 & \multirow{2}{*}{101} & 2.27 & $.025^{*}$ \\
\hline * $\mathrm{p}<.05$ & Kontrol & 49 & 120.16 & 22.29 & & & \\
\hline
\end{tabular}

Deney ve kontrol grubu akademik başarı ön test ortalama puanları arasında anlamlı bir fark olmadığı belirlenmiştir. Deney ve kontrol gruplarının biyoloji dersine ilişkin tutum ön test ortalama puanları arasında anlamlı bir fark bulunmuştur $\left(\mathrm{t}_{(101)=} 2.27, \mathrm{p}<.05\right)$.

\section{ikinci Alt Probleme ilişkin Bulgular}

Çalışmada deney ve kontrol grubu değişkenlerine göre öğrencilerin ön test puanları kontrol altına alındığında son test puanlarında anlamlı bir farklılaşma olup olmadığına bakmak için bu alt problem ANCOVA ile test edilmiştir. Analiz için öncelikle ANCOVA'nın varsayımlarının karşılanıp karşılanmadığı incelenmiştir. Buna göre; uç ve kayıp değerlerin olmadığı, Shapiro-Wilks testi ( $p>05$ ) ile grup puanlarının normalliğe uygun olduğu, gruplara ait ön ölçümler ile son ölçümler arasında doğrusal bir ilişki olduğu ve son ölçümlere ait bağımlı değişkene ilişkin varyansların eşit olduğu (Levene F Testi p>.05) tespit edilmiştir. Varsayımların sağlandığı belirlendikten sonra analiz gerçekleştirilmiştir. Deney ve kontrol gruplarının akademik başarı son test sonuçları Tablo 3'te gösterilmektedir.

Tablo 3: Deney ve Kontrol Grubu Akademik Başarı Son test Puanlarına Göre ANCOVA Sonuçları

\begin{tabular}{lccccc}
\hline & $\mathrm{N}$ & \multicolumn{2}{c}{ Düzeltilmemiş Ortalama } & \multicolumn{2}{c}{ Düzeltilmiş Ortalama } \\
\hline Deney & 54 & \multicolumn{2}{c}{24.19} & 23.696 \\
Kontrol & 49 & \multicolumn{2}{c}{22.78} & $\mathrm{~F}$ & 23.315 \\
\hline Varyansın Kaynağı & Kareler Toplamı & sd & Kareler Ortalaması & 64.66 & $.000^{*}$ \\
\hline Model & 1269.826 & 2 & 634.913 & 124.124 & $.000^{*}$ \\
Öntest (Reg) & 1218.777 & 1 & 1218.777 & .371 & .544 \\
Grup & 3.640 & 1 & 3.640 & 9.819 & \\
Hata & 981.902 & 100 & & & \\
Toplam & 59204.000 & 103 & & &
\end{tabular}

Tablo 3'de verildiği gibi deney ve kontrol gruplarının akademik başarı ön testine göre düzeltilmiş son test ortalama puanları arasındaki farkın anlamsız olduğu tespit edilmiştir $\left(\mathrm{F}_{(1 ; 100)}=.371 ; \mathrm{p}>.05\right)$. Bu sonuç, akademik başarı son test puanları açısından deney ve kontrol gruplarının farklılık göstermediği bulunmuştur.

\section{Üçüncü Alt Probleme iliş̧kin Bulgular}

Deney ve kontrol gruplarının akademik başarı ön test-son test ortalama puanlarının ilişkili örneklemler t-testi sonuçları Tablo 4'te verilmiştir. 
Tablo 4: Deney ve kontrol grubunun akademik başarı ön test-son test ortalama puanlarının ilişkili örneklemler t-testi sonuçları

\begin{tabular}{clcccccc}
\hline & & $\mathrm{N}$ & $\overline{\mathrm{X}}$ & $\mathrm{S}$ & $\mathrm{sd}$ & $\mathrm{t}$ & $\mathrm{p}$ \\
\hline \multirow{2}{*}{ Deney grubu } & Ön test & 54 & 21.20 & 4.24 & & & \\
& Son test & 54 & 24.19 & 4.22 & 53 & 6.77 & $.000^{*}$ \\
\multirow{2}{*}{ Kontrol grubu } & Ön test & 49 & 19.88 & 4.72 & & & \\
& Son test & 49 & 22.78 & 5.116 & & 6.11 & $.000^{*}$ \\
\hline${ }_{*}<<.05$ & & & & & & &
\end{tabular}

Deney grubunun uygulama öncesi akademik başarı puanlarının ortalaması $\bar{X}=21.20$ iken, uygulama sonrasında $\bar{X}=24.19$ 'a yükselmiştir. Yani deney grubunun kavram haritalama öğretim süreci sonunda son test akademik başarılarında ön testlerine göre son testlerinde anlamlı bir artş olduğu tespit edilmiştir $\mathrm{t}_{(53)}=6.77, \mathrm{p}<.05$. Bu bulgu, kavram haritalama öğretim yönteminin başarıyı arttırmada bir etkiye sahip olduğunu göstermektedir.

Kontrol grubunun uygulama öncesi akademik başarı puanlarının ortalaması $\bar{X}=19.88$ iken, uygulama sonrasında $\bar{X}=22.78$ 'e yükselmiştir. Yani kontrol grubunun geleneksel öğretim süreci sonunda akademik başarılarında ön testlerine göre son testlerinde anlamlı bir arţ̧̧ olduğu bulunmuştur $\mathrm{t}_{(48)}=6.11, \mathrm{p}<.05$. Bu bulgu, geleneksel öğretim yönteminin başarıyı arttırmada bir etkiye sahip olduğunu göstermektedir.

\section{Dördüncü Alt Probleme ilişskin Bulgular}

Araştirmada yapılan istatistiksel analiz sonucunda tutum ön testinde anlamlı fark tespit edildiği için gruplar birbirine denk değildir. Çalışmada deney ve kontrol grubu değişkenlerine göre öğrencilerin ön test puanları kontrol altına alındığında son test puanlarında anlamlı bir farklılaşma olup olmadığına bakmak için bu alt problem ANCOVA ile test edilmiştir. Analiz için öncelikle ANCOVA'nın varsayımlarının karşılanıp karşılanmadığı incelenmiştir. Buna göre; uç ve kayıp değerlerin olmadığı, Shapiro-Wilks testi ( $p>.05)$ ile grup puanlarının normalliğe uygun olduğu, gruplara ait ön ölçümler ile son ölçümler arasında doğrusal bir ilişki olduğu ve son ölçümlere ait bağımlı değişkene ilişkin varyansların eşit olduğu (Levene F Testi p>.05) tespit edilmiştir. Varsayımların sağlandığı belirlendikten sonra analiz gerçekleştirilmiştir.

Deney ve kontrol gruplarının tutum son test sonuçları Tablo 5'de verilmiştir.

Tablo 5: Deney ve Kontrol Gruplarının Tutum Son Test Puanlarına Göre ANCOVA Sonuçları

\begin{tabular}{lccccc}
\hline & $\mathrm{N}$ & \multicolumn{2}{c}{ Düzeltilmemiş Ortalama } & \multicolumn{2}{c}{ Düzeltilmiş Ortalama } \\
\hline Deney & 54 & \multicolumn{2}{c}{134.02} & 130.866 \\
Kontrol & 49 & \multicolumn{2}{c}{123.94} & 127.413 \\
\hline Varyansın Kaynağı & Kareler Toplamı & sd & Kareler Ortalaması & $\mathrm{F}$ & $.000^{*}$ \\
\hline Model & 24666.951 & 2 & 12333.467 & 86.279 & $.000^{*}$ \\
Öntest (Reg) & 22056.885 & 1 & 22056.885 & 154.299 & .157 \\
Grup & 291.299 & 1 & 291.299 & 2.038 & \\
Hata & 14294.913 & 100 & & & \\
Toplam & 1758924.000 & 103 & & &
\end{tabular}

Tablo 5'te verildiği gibi deney ve kontrol gruplarının tutum ön testine göre düzeltilmiş son test ortalama puanları arasındaki farkın istatistiksel olarak önemli olmadığı tespit edilmiştir $\left(F_{(1 ; 100)}=2.038 ; p>.05\right)$. Bu sonuç, deney ve kontrol gruplarının tutum son test puanlarının farklı olmadığını göstermektedir. Bir diğer deyişle deney ve kontrol gruplarına ait son test tutum puanları arasında istatistiksel bir fark yoktur, deney ve kontrol gruplarının son test tutum puan düzeyleri aynıdır.

\section{Beşinci Alt Probleme ilişkin Bulgular}

Deney ve kontrol gruplarının tutum ön test-son test ortalama puanlarının bağımlı örneklemler t-testi sonuçları Tablo 6'da verilmiştir. 
Tablo 6: Deney ve kontrol grubunun tutum ön test-son test puanlarının ilişkili örneklemler t-testi sonuçları

\begin{tabular}{llcccccc}
\hline & & $\mathrm{N}$ & $\overline{\mathrm{X}}$ & $\mathrm{S}$ & $\mathrm{sd}$ & $\mathrm{t}$ & $\mathrm{p}$ \\
\hline \multirow{2}{*}{ Deney grubu } & Ön test & 54 & 129.57 & 19.718 & & & \\
& Son test & 54 & 134.02 & 15.586 & 53 & 2.332 & $.024^{*}$ \\
\multirow{2}{*}{ Kontrol grubu } & Ön test & 49 & 120.16 & 22.299 & & & \\
& Son test & 49 & 123.94 & 22.116 & 48 & 2.07 & $.043^{*}$ \\
\hline${ }^{*} \mathrm{p}<.05$ & & & & & & &
\end{tabular}

Tablo 6'da deney grubu uygulama öncesi tutum puanları ortalaması $\bar{X}=129.57$ iken, uygulama sonrasında $\bar{X}=134.02$ 'ye yükselmiştir. Yani deney grubunun kavram haritalama öğretim süreci sonunda biyoloji dersine yönelik tutumlarında ön testlerine göre son testlerinde anlamlı bir artış olduğu tespit edilmiştir $\left(\mathrm{t}_{(53)}=2.33, \mathrm{p}<.05\right)$.

Kontrol grubunun uygulama öncesi tutum puanlarının ortalaması $\bar{X}=120.16$ iken, uygulama sonrasında $\bar{X}=123.94$ 'e yükselmiştir. Yani kontrol grubunun geleneksel öğretim süreci sonunda biyoloji dersine yönelik tutumlarında ön testlerine göre son testlerinde anlamlı bir artş̧ bulunmuştur $t_{(48)}=2.07, p<.05$. Bu bulgu, geleneksel öğretim yönteminin de biyoloji dersine yönelik olumlu tutum geliştirmede bir etkiye sahip olduğunu göstermektedir.

\section{Tartışma ve Sonuç}

Bu araştırmada, genel biyoloji dersinde kavram haritalama ve geleneksel öğretim yöntemlerini kullanmanın öğretmen adaylarının akademik başarısı ve biyoloji dersine yönelik tutumları üzerindeki etkileri incelenmiştir.

Yapılan istatistiksel analizlerde, araştırmanın öncesinde gruplara uygulanan akademik başarı testinden elde edilen sonuçlara göre gruplar arasında fark olmadığı bulunmuştur. Buradan hareketle deney ve kontrol gruplarının akademik başarı testi puanları açısından denk oldukları söylenebilir.

Deneysel çalışma sonrasında uygulanan akademik başarı testi sonuçlarına göre deney ve kontrol gruplarının son testleri arasında istatistiksel olarak anlamlı bir fark olmadığı saptanmıştır. Bu araştırmada kullanılan geleneksel yöntem de kavram haritaları ile öğretim de başarılı olmuştur. Kavram haritaları kullanılarak gerçekleştirilen öğretim sonucu öğrenme başarısııın, geleneksel yöntemin kullanıldığı öğretim yöntemine göre biraz daha yüksek olduğu ancak aralarında anlamlı bir fark olmadığı anlaşılmıştır. Bu sonuç üzerinde her iki gruptaki öğretmen adaylarının hazır bulunuşluk düzeylerinin etkili olduğu söylenebilir. Hazır bulunuşluk düzeyi yüksek olan birey konuları daha çabuk kavrayarak konu ile ilgili yorum yapabilir. Birey konuyu ve konu ile ilgili kavramları öğrendiği için ödevleri kolaylıkla yapabilir, bir önceki konuyu iyi öğrendiği için sonraki konuyu öğrenmek için daha hazır hale gelebilir (Harman ve Çelikler, 2012).

Kavram haritalarının başarıya katkısı açısından değerlendirildiğinde dersin her aşamasında kullanılıyor olması, olaylar arasında neden sonuç ilişkisi kurmaya teşvik etmesi, konuyu özetlemesi, aktif öğrenmeye teşvik etmesi, kavramların hatırda kalabilmesini kolaylaştırması ve kavramlar arasında ilişkilendirme yapabilme yetisini güçlendirerek akademik başarıya katkı sağladığı düşünülebilir. Bu çalışma sonuçları genel olarak değerlendirildiğinde biyoloji dersinin öğretim açısından hem kavram haritaları ile öğretime hem de geleneksel öğretim yöntemine katılan öğrencilerin bilgi düzeylerinde artş̧ olduğu söylenebilir. Fakat başarı oranına bakıldığında kavram haritası yönteminin geleneksel öğretim yöntemine göre, öğrencilerin bilgilerini artırmada daha etkili olduğu anlaşılmaktadır. Kavram haritalamanın geleneksel yönteme göre başarıyı artırmada daha etkili oluşunu, öğrencilerin yeni bilgileri öğrenirken eski bilgilerini kullanmalarına, yaşlarını ve farklı zihinsel gelişmişlik düzeylerine sahip olmalarına bağlayabiliriz. Bu bağlamda kavram haritaları öğrencilerin bilgi düzeylerini değerlendirilebilmek için de kullanılabilir. Dolayısıyla öğrencilerin problem çözme, eleştirel düşünme yeteneklerini geliştiren kavram haritaları, bir öğrenme öğretme aracı olduğu kadar, bir değerlendirme aracı olarak da kullanılmaktadır (Öztürk ve Karayağız, 2006).

Yapılan alan yazın taramasında gerçekleştirilen bu araştırma sonuçları ile farklı araştrıcıların elde ettikleri sonuçlar arasında benzerlik olduğu görülmüştür. Kulaberoğlu ve Gürdal (2001) yapttkları çalışmada geleneksel yöntem ve kavram haritalama yöntemi uygulama sonuçları arasında anlamlı bir fark bulamamışlardır. Ancak kavram haritası yönteminin öğrenci başarısını geleneksel yöntemden daha ileriye götüreceği hipotezinin kabulünü destekleyecek derecede, farklılığın sadece ortalamalar bazında var olduğunu söylemişlerdir. Çimer ve Çimer (2002) konuların tekrar edilmesinde kavram haritalarının kullanımı ile ilgili yaptıkları çalışmada bütün ünitelerde öğrencilerin akademik başarısında görülen arţ̧̧ı istatistiki olarak önemsiz olduğunu tespit etmişlerdir. Ekmekçioğlu (2007) ortaöğretim öğrencileriyle kimya dersinde, asit baz konusunun kavram haritası ile öğrenme ve başarıya etkisi ile ilgili yaptıkları çalışmada kullanılan geleneksel yönteme göre kavram haritaları ile öğretim yönteminin öğretim sürecinde boyunca daha etkili olduğunu bulmuş- 
lardır. Bu sonuç bu çalışmadan elde edilen sonucu destekler niteliktedir. Erdoğan (2007) kavram haritalarının kullanımı öğrenci başarısı için memnun edici bir yaklaşım olarak görülse de beklentilerin tamamını karşılayacak seviyede olmadığını belirtmiştir. Akay (2010) lise 3. sınıf biyoloji dersi boşaltım sistemi konusunun kavram haritaları ile öğretilmesinin öğrencilerin akademik başarısına ve tutumlarına etkisi konulu çalışmasında kontrol grubundaki öğrencilerin ön test le son test puan ortalamaları arasında son test puanları lehine bir farklılık olduğunu belirtmektedir. Kavram haritalamanın her zaman başarıyı olumlu yönde etkilemediğini belirten çalışmalar da bulunmaktadır (Çömek ve diğ, 2016).

Biyoloji eğitiminde önemli hedeflerinden biri kavramların anlamlı ve akılda kalıcı öğrenilmesi ile doğru kullanımını sağlamaktır. Bu hedefe ulaşmak için uygun öğretim yönteminin seçimi önemlidir. Bu araştırmadan elde edilen sonuçlarda kavram haritaları ile yapılan öğretimin öğrenci başarısını olumlu yönde etkilediğini destekler niteliktedir.

Çeşitli araştırmacılar tarafindan yapılan çalışmalarda da kavram haritaları ile yapılan öğretimin başarıyı olumlu yönde etkilediğine ilişkin bilgiler bulunmaktadır. (Akınoğlu ve Yaşar, 2007; Qarareh, 2010; Yılmaz, Akandere ve Korkmaz, 2010; Evrekli ve Balım, 2010; Batdı, 2014; Maleki ve Dabbaghi, 2014; Chawla ve Singh, 2015; Çömek ve diğ., 2016).

Yapılan bu çalışmada aynı zamanda biyoloji dersinde kavram haritaları kullanımının öğrencilerin biyoloji dersine karşı tutumlarına olan etkisi de araştrılmıştır.

Kavram haritası çalışması sonrasında yapılan t testi ile deney ve kontrol grupları tutum ön test-son test karşılaştırması istatistiksel olarak son test lehine farklıdır $(p<.05)$. Elde edilen bu sonuçtan hareketle, 10 haftalık süre sonunda kavram haritası kullanımının öğretmen adaylarının biyoloji dersine olan tutumlarına anlamlı bir etkisi olduğu sonucuna varılmıştır. Ancak deney ve kontrol gruplarının son test sonuçları farklı değildir. Dolayısıyla hem geleneksel hem de kavram haritalama yönteminin aynı düzeyde etkili olduğu söylenebilir. Araştırmadan elde edilen bulgular, tutum ile ilgili yapılmış çalışmalardan elde edilen bulgularla paralellik göstermektedir.

Ekmekçioğlu (2007) yaptığı çalışmada ortaöğretim kimya dersinde asit baz konusunun öğretiminde kavram haritasının kullanımının ve anlamlı öğrenme kuramının, bilimsel başarıya ve öğrencilerin kimya dersine olan tutumları incelemiş, deney grubu öğrencilerinin kimya dersine olan tutumlarının ön testlerine göre daha yüksek olduğu, kontrol grubu öğrencilerinin tutumlarında ise herhangi bir değişiklik olmadığı soncuna varmıştı. Başka bir çalışmada ise lise 3.sınıf biyoloji dersi boşaltım sistemi konusunun kavram haritaları ile verilen bilişsel desteğin öğrencilerin başarılarına, fen dersi ile ilgili tutumlarına ve öğretilen bilgilerin akılda kalıcılığına olumlu etkileri olduğu tespit edilmiştir (Akay ,2010).

Buna karşın yapılan alan yazın incelemelerinde kavram haritası kullanımının derse yönelik tutumu olumlu yönde değiştirdiğini tespit eden araştırmalar da bulunmuştur (Novak ve Gowin 1984; Binzat, 2000; Türkmen ve diğ., 2005; Güçlüer, 2006; Akınoğlu ve Yaşar, 2007; Altunay ve Şeker, 2008; Kendirli, 2008; Yılmaz ve Çolak, 2012; Batdı, 2014; Lin ve diğ., 2015). Bu araştırmalardan elde edilen benzer sonuçlar, kavram haritalarının tutum üzerindeki olumlu etkisi, ilgili çalışmalardaki uygulanan deneysel yöntemin nasıl kurgulandığına, hangi sınıf düzeyine göre yapıldığına ve en önemlisi uygulama süresine bağlı olarak değişkenlik gösterir düşüncesini destekler doğrultudadır (Çömek ve diğ., 2016).

Sonuç olarak kavram haritalarının tek başına öğretme stratejisi olarak kullanıldığında yetersiz olabileceği, diğer sınıf içi aktiviteler ile birlikte uygulandığı zaman ise maksimum başarı sağladığı çeşitli çalışmalarda ifade edilmiştir (Kinchin, 2000; Akgündüz ve Bal, 2013). Çalışmamızda öğrencilerin konuları eksik bilmelerinden ya da kavram yanılgılarından dolayı kavram haritası çizmekte zorlandıkları görülmüş bu da onların istekli bir şekilde kavram haritası yapmasını engellemiş böylece kavram haritalamanın başarıya etkisini azaltmış olabilir. Kılınç (2007) ve Uzuntiryaki (1998) eksik bilgilerin ve kavramlar arasındaki bağlantıların çokluğunun kavram haritalamadaki isteği ve ders başarısını düşürebileceğini belirtmişlerdir. Yapılan çalışmalar, kavram haritası tekniği ilk öğretildiği zaman ustalık kazanana kadar en az 10 haftalık süre geçmesinin gerekli olduğunu göstermiştir (Lehman ve diğ., 1985; Wandersee, 1990).

Araştırma süresince öğrenciler 10 haftalık bir süre boyunca biyoloji derslerinde kavram haritası çizmiş olmalarına rağmen öğrencilerin daha önceden kavram haritası çizme deneyimlerinin olmaması pratiklik konusunda yavaş olmalarına ve süreyi ekonomik kullanamamalarına neden olmuştur. Bu da kavram haritası çiziminde öğrencilerin karşılaştkları problemler olarak belirtilebilir. Kavram haritalama için yeterli zamanın verilmesinin önemli olduğu Çimer ve Çimer (2002) 'in yaptıkları çalışmalarında belirtilmiş̧tir.

Kavram haritaları genellikle kalem-kâğıt aracılığıyla çizildiği ve bu yüzden yeni kavram ekleyip çıkarmak zor olabileceği için bu durum öğrencilerin dikkatini azalttp öğrenmenin etkililiğini azaltmaktadır (Çakmak ve Baysen, 2013). Uygulamalar esnasında kavramların sayıca fazla oluşunun öğrencilerin harita yapmakta zaman zaman isteksizliklere sebep olduğu gözlemlenmiştir. Bu durumun da sonuçlar üzerinde etkili olabileceği düşünülmektedir. 
Öğretmen adaylarından gelen dönütlere göre bağlantı cümlelerini yazmakta zorlandıkları tespit edilmiştir. Bağcı (2003), Türkçede cümle içindeki söz dizisinin İngilizceye göre farklılıklar göstermesinden dolayı Novak tarzında Türkçe kavram haritaları yaparken zorluklar yaşandığını belirtmiştir. Bu sebeple bağlantı cümlelerini doğru kullanamayan öğrencilerde bir başarısızık hissi oluşmuş olabilir.

\section{Öneriler}

Bu çalışmadan elde edilen sonuçlara bağlı olarak şu önerilerde bulunulabilir;

- Kavram haritasına yapılmadan önce anahtar kavramlar doğru olarak seçilmelidir.

- Kavram haritası eğitimi ve yapımı için yeterli zaman ayrılmalıdır.

- Kavram haritalarııı çiziminde kavramların daha kolay yerleştirilip çıkarılması için bilgisayar destekli kavram haritalarından faydalanılabilir.

- Kavram haritaları farklı öğretim kademeleri için uygun bir eğitim aracı olup, öğretmen ve öğrenciler tarafindan bir öğrenme, öğretme ve değerlendirme aracı olarak eğitim öğretim ortamlarında kullanılmalıdır.

\section{Kaynakça}

Açar, B. (2007). Öğrencilerin kuvvet konusundaki başarılarının kavram haritası ile ölçülmesi. Yayımlanmamış Yüksek Lisans Tezi. Gazi Üniversitesi, Eğitim Bilimleri Enstitüsü, Ankara.

Akay, S. Ö. (2010). Lise 3. sınıf biyoloji dersinde okutulan boşaltım sistemi konusunun kavaram haritaları ile öğretilmesinin öğrencilerin akademik başarısına ve tutumlarına etkisi. Yüksek Lisans Tezi. Selçuk Üniversitesi, Eğitim Bilimleri Enstitüsü, Konya.

Akay, S. Ö., Kaya, B., \& Kilıç, S. (2012). The effects of concept maps on the academic success and attitudes of 11th graders while teaching urinary system. International Journal of New Trends in Arts, Sports \& Science Education (IJTASE), 1(3), 55-62.

Akbaş, Y. \& Toros, S. (2016). Sosyal bilgiler öğretiminde interaktif kavram karikatürleri ve kavram haritaları kullanımının akademik başarıya etkisi. Electronic Turkish Studies, 11(9).

Akgündüz, D. \& Bal, Ş. (2013). Illköğretim fen bilgisi dersi 6. Sınıf biyoloji konularında kavram haritalarının kullanılmasının öğrencilerin akademik başarılarına ve tutumlarına etkisi. 21. Yüzyılda Eğitim ve Toplum Eğitim Bilimleri ve Sosyal Araştırmalar Dergisi, 2(5).

Akınoğlu, O. \& Yaşar, Z. (2007). The effects of note taking in science education through the mind mapping technique on students' attitudes, academic achievement and concept learning. Journal of Baltic Science Education, 6(3), 34-43.

Altınok, H. (2004). İşbirlikli Öğrenme, Kavram Haritalama, Fen Başarısı, Strateji Kullanımı ve Tutum. Doktora Tezi. Dokuz Eylül Üniversitesi, Eğitim Bilimleri Enstitüsü, İzmir.

Altunay, A. Y. \& Şeker, R. (2008). Bilgisayar ortamında hazırlanan kavram haritalarııı bir öğretim materyali olarak fen bilgisi dersinde kullanılmasının ilköğretim öğrencilerinin başarılarına etkisi. Türkiye Sosyal Araştırmalar Dergisi, 12(3), 19-32.

Ausubel, D.P. (1968). Educational Psychology, New York: Holt, Rinehart ve Winston.

Aykanat, F., Doğru, M. \& Kalender, S. (2005). Bilgisayar destekli kavram haritaları yöntemiyle fen öğretiminin öğrenci başarısına etkisi. Kastamonu Eğitim Dergisi, 13(2), 391-400.

Aykutlu, I. \& Şen, A. I. (2012). Üç aşamalı test, kavram haritası ve analoji kullanılarak lise öğrencilerinin elektrik akımı konusundaki kavram yanılgılarının belirlenmesi. Eğitim ve Bilim, 37(166), 275.

Bağcı, K. G. (2003). Concept maps and language: A turkish experience, International Journal of Science Education, 25(11), 1299- 1311.

Batdı, V. (2014). Kavram haritası tekniği ile geleneksel öğrenme yönteminin kullanılmasının öğrencilerin başarıları, bilgilerinin kalııılığı ve tutumlarına etkisi: Bir meta-analiz çalışması. Dumlupınar Üniversitesi Sosyal Bilimler Dergisi, (42).

Bayram, H. \& Ersoy, N. (2014). 7. sınıf öğrencilerinin maddelerin sınıflandırılması ve değişimi konusundaki kavram yanılgılarının deney ve kavram haritası yöntemi ile giderilmesi. Eğitim Bilimleri Dergisi, 40, 31-46.

Binzat, O. (2000). Kavram haritalama ve diğer değişkenlerin insan boşaltım sisteminin öğrenilmesine etkisi. Yüksek Lisans Tezi. Orta Doğu Teknik Üniversitesi, Fen Bilimleri Enstitüsü, Ankara.

Büyüköztürk, Ş. (2010). Sosyal Bilimler İçin Veri Analizi El Kitabı (11.Baskı b.). Ankara: Pegem A Yayıncılık.

Canbolat, S. (2008). Fen teknoloji dersinde kavram haritası kullanımının öğrencilerin tutumları ve başarılarına etkisi. Yayınlanmamış Yüksek Lisans Tezi. Gazi Üniversitesi, Eğitim Bilimleri Enstitüsü, Ankara.

Chawla, J., \& Singh, G. (2015). Effect of concept mapping strategy on achievement in chemistry of ix graders in relation to achievement motivation. Asia Pacific Journal of Research, 1(24), 53-65.

Çağlayan, Ç. (2006). Sekizinci sınıf fen bilgisi dersi genetik ünitesinin öğretiminde kavram haritalarııın kullanımını öğrencilerin akademik başarılarına ve kavram kazanmalarına etkisi. Yüksek Lisans Tezi. Çukurova Üniversitesi, Sosyal Bilimler Enstitüsü, Adana.

Çakmak, N. \& Baysen, E. (2013). Kavram haritalarının bilgi arama süreçlerinde kullanılması. Bilgi Dünyası, 14(2), 358-372.

Çetinkaya, M. \& Taş, E. (2011). Canlıların sınıflandırılması için web destekli kavram haritaları ve anlam çözümlemesi tablolarının öğrenme hakkındaki etkisini araştrııması. Dicle Üniversitesi Ziya Gökalp Eğitim Fakültesi Dergisi, 16, 180-195. 
Çimer, A. \& Çimer, O. S. (2002). Öğrencilerin biyoloji konularının tekrar edilmesinde bir araç olarak kavram haritası tekniğini kullanmaya karşı tutumları. V. Ulusal Fen Bilimleri ve Matematik Eğitimi Kongresi, 16-18 Eylül, Ankara.

Çömek, A., Akınoğlu, O., Elmacı, E. \& Gündoğdu, T. (2016). The effect of concept mapping on students' academic achievement and attitude in science education. Journal of Human Sciences, 13(1), 348-363.

Demirci, C. (2003). Fen bilgisi öğretiminde etkin öğrenme yaklaşımının erişi, tutum ve kalııılığa etkisi. Yayınlanmamış Doktora Tezi. Hacettepe Üniversitesi, Sosyal Bilimler Enstitüsü, Ankara.

Doğru, P. (2002). Kavramsal değişim metinleri ve kavram haritaları kullanılarak öğrencilerin difüzyon ve osmoz konularında kavramsal değişimin geliştirilmesi. Yüksek Lisans Tezi. Orta Doğu Teknik Üniversitesi, Fen Bilimleri Enstitüsü, Ankara.

Ekmekçioğlu, E. (2007). Ortaöğretim kimya dersinde asit baz konusunun anlamlı öğrenme kuramı ve kavram haritası ile öğretiminin başarıya etkisi. Doktora Tezi. Selçuk Üniversitesi, Fen Bilimleri Enstitüsü, Konya.

Erdem, E. (2008). Genel kimya dersinde öğrencilerin kavram haritalama ve problem çözme inancının incelenmesi. Hacettepe Üniversitesi Eğitim Fakültesi Dergisi, 35(35).

Erdoğan, A. (2007). Kavram haritalarının calculus öğretiminde kullanılması. Yayımlanmamış Doktora Tezi. Selçuk Üniversitesi, Fen Bilimleri Enstitüsü, Konya.

Erdoğan, Y. (2016). An investigation of the effectiveness of concept mapping on Turkish students' academic success. Journal of Education and Training Studies, 4(6), 1-9.

Esiolu, G. \& Soyibo, K. (1995). Effects of concept and vee mapping under three learning models on students' cognitive achievement in ecology and genetics. Journal Of Research In Science Teaching , 32 (9), 971-995.

Evrekli, E., İnel, D. \& Balım, A. G. (2009). Kavram ve zihin haritası kullanımının öğrencilerin kavramları anlama düzeyleri ile fen ve teknolojiye yönelik tutumları üzerindeki etkileri. Abant İzzet Baysal Üniversitesi Eğitim Fakültesi Dergisi, 229-250.

Evrekli, E. \& Balım, A. G. (2010). Fen ve teknoloji öğretiminde zihin haritası ve kavram karikatürü kullanımının öğrencilerin akademik başarılarına ve sorgulayıcı öğrenme becerileri algılarına etkisi. Batı Anadolu Eğitim Bilimleri Dergisi (BAED), 1(2), 76-98.

Güçlüer, E. (2006). illköğretim fen bilgisi eğitiminde kavram haritaları ile verilen bilişsel desteğin başarıya, hatırda tutmaya ve fen bilgisi dersine ilişkin tutuma etkisi. Yüksek Lisans Tezi. Dokuz Eylül Üniversitesi, Eğitim Bilimleri Enstitüsü, İzmir.

Güneş, T., Güneş, M. H., \& Çelikler, D. (2006). Fen bilgisi öğretmenliği programı biyoloji II ders konularının öğretilmesinde kavram haritası kullanımının öğrenci başarısı üzerine etkileri. Kırşehir Eğitim Fakültesi Dergisi, 7(2), 39-49.

Günhan, F. (2009). Kavram haritaları öğretim stratejisinin öğrenci başarısına etkisi: bir meta analiz çalışması. Yüksek Lisans Tezi. Marmara Üniversitesi, Eğitim Bilimleri Enstitüsü, İstanbul.

Gürlek, M. (2002). Ortaöğretim biyoloji (botanik) öğretiminde anlam çözümleme tabloları, kavram ağları ve kavram haritalarının uygulanması. Yüksek Lisans Tezi. Yüzüncü Yıl Üniversitesi, Fen Bilimleri Enstitüsü, Van.

Harman, G. \& Çelikler, D. (2012) Eğitimde Hazır Bulunuşluğun Önemi Üzerine Bir Derleme Çalışması. Eğitim ve Öğretim Araştırmaları Dergisi, cilt (1),3.

Kalaycı, N. (2001). ỉki boyutlu görsel öğrenme ve öğretme araçları. 10. Ulusal Eğitim Bilimleri Kongresi. Abant İzzet Baysal Üniversitesi.

Kaptan, F. (1998). Fen öğretiminde kavram haritası yönteminin kullanılması. Hacettepe Üniversitesi Eğitim Fakültesi Dergisi, $14,95-99$.

Kasapoğlu, E. (2011). Lise 12. sınıf biyoloji dersi protein sentezi konusunun kavram haritalarıyla öğretiminin öğrencilerin akademik başarılarına ve tutumlarına etkisi. Doktora Tezi. Selçuk Üniversitesi, Eğitim Bilimleri Enstitüsü, Konya.

Kaya, O. N. \& Ebenezer, J. V. (2003). Alongitudinal study of the effects of concept mapping and vee diagramming on senior university students' achievement, attitudes and perceptions in science laboratory. Paper presented at the annual conference of the National Association for Research in Science Teaching (NARST, USA), Philadelphia, March.

Kaya, O. N. (2003a). Eğitimde alternatif bir değerlendirme yolu: kavram haritaları. Hacettepe Üniversitesi Eğitim Fakültesi Dergisi, 25(25).

Kaya, O. N. (2003b). Fen eğitiminde kavram haritaları. Pamukkale Üniversitesi Eğitim Fakültesi Dergisi, 1(13), 70-79.

Kendirli, B. (2008). Fen ve teknoloji dersinde kavram haritası kullanımının öğrenci tutumu, başarısı ve bilgi kalııılığına etkisi. Yayınlanmamış Yüksek Lisans Tezi. Gazi Üniversitesi, Eğitim Bilimleri Enstitüsü, Ankara.

Kılınç, U. A. (2007). Bir öğretim stratejisi olarak kavram haritalarının kullanımı. Yüzüncü Yıl Üniversitesi Eğitim Fakültesi Dergisi, 4(2), 21-48.

Kinchin, I. (2000). Concept mapping in biology. Journal of Biological Education, 34 (2), s. 61-68.

Kulaberoğlu, N. \& Gürdal, A. (2001). Fen bilgisi derslerinde kavram haritaları yönteminin öğrenci başarısına etkisi. Yeni Binyılın Başında Türkiye'de Fen Bilimleri Eğitimi Sempozyumu, Maltepe Üniversitesi, 7-8.

Lehman, J., Carter, C. \& Kahle, J. (1985). Concept mapping, vee mapping, and achievement: results of a field study with black high school students. Journal of Research in Science Teaching , 22 (7), s. 663-672.

Lin, Y. T., Chang, C. H., Hou, H. T. \& Wu, K. C. (2015). Exploring the effects of employing google docs in collaborative concept mapping on achievement, concept representation, and attitudes. Interactive Learning Environments, 1-22.

Maleki, M., \& Dabbaghi, A. (2014). The influences of concept mapping strategy on reading comprehension of those students challenging in studying invalid books at some high schools. International Journal of Psychology and Behavioral Research, 3 (1), 44-54. 
Novak, J. (2002). Meaningful Learning: The Essential Factor for Conceptual Change in Limited or Inappropriate Propositonal Hiearcihies Leading to Empowerment of Learners. Science Education, 86, s. 548-571.

Novak, J. D. \& Gowin, D. B. (1984). Learning how to learn. Cambridge; New York: Cambridge University Press.

Novak, J.D., Gowin, D.B. \& Johansen, G.T. (1983). The use of concept mapping and knowledge vee mapping with junior high school science students. Science Education, 67(5), 625-645.

Öztürk, C., \& Karayağız, G. (2006). Teori ile uygulama arasında yeni bir köprü: Kavram haritası. CÜ Hemşirelik Yüksekokulu Dergisi, 10(1), 29-31.

Pehlivan, H. \& Köseoğlu, P. (2010). The reliability and validity study of the attitude scale for biology course. Procedia Social and Behavioral Sciences 2, 2, s. 2185-2188.

Polat, B. \& Doğan, N. (2015). Vee diyagramı, tanılayıcı dallanmış ağaç, kavram haritalarının matematik dersine yönelik tutum ve başarıya etkileri. Eğitimde Kuram ve Uygulama, 11(3), 851-874.

Qarareh, A. O. (2010). The effect of using concept mapping in teaching on the achievement of fifth graders in science. Stud Home Comm Sci, 4(3), 155-160.

Sarıca, R. \& Çetin, B. (2012). Öğretimde kavram haritaları kullanımının öğrencilerin akademik başarısına ve kalıcılığa etkisi. İlköğretim Online, 11(2).

Şimşek, A. (2006). Kavramların öğretimi. Ali Şimşek (Editor). lç̧erik türlerine dayalı öğretim içinde (s. 27-70). Ankara: Nobel.

Tabachnick B. G. and Fidell L. S. (2013) Using Multivariate Statistics (sixth ed.). Pearson: Boston.

Taricani, E.M. (2002). Effects of the level of generativity in concept mapping with knowledge of correct response feedback on learning. Ph.D. Thesis. The Pennsylvania State University, ABD. Retrieved November 11, 2017 from https://www.learntechlib.org/p/118235/.

Tavşancıl, E. (2002). Tutumların ölçülmesi ve SPSS ile veri analizi. Ankara: Nobel Yayıncılık.

Türkmen, L., Çardak, O. \& Dikmenli, M. (2005). Lise 1 biyoloji dersi alan öğrencilerin canlıların çeşitliliği ve sınıflandırılmasıyla ilgili kavram yanılgılarının belirlenmesi ve kavram haritası yardımıyla değiştirilmesi. Gazi Eğitim Fakültesi Dergisi , 25(1), s. 155-168.

Ural, A., ve Kılıç, I. (2005). Bilimsel Araştırma Süreci ve SPSS Veri Analizi. Ankara: Detay Yayıncılık.

Uzuntiryaki, E. (1998). Kavram haritası destekli kavram değiştirme yönteminin öğrencilerin çözelti konusunu anlamalarına etkisi. Yüksek Lisans Tezi. Orta Doğu Teknik Üniversitesi, Fen Bilimleri Enstitüsü, Ankara.

Wandersee, J. H. (1990). Concept mapping and the cartography of cognition. Journal of research in science teaching, $27(10), 923-936$.

Yavuz, S. \& Büyükekşi, C. (2015). Tepkime hızı konusundaki öğrenci kavram haritalarının değerlendirilmesi. Karaelmas Eğitim Bilimleri Dergisi, 3(2).

Yılmaz, H., Akandere, O. \& Korkmaz, İ. (2010). İlköğretim birinci kademe 5. sınıf sosyal bilgiler dersinde kavram haritalarının kullanılmasının başarıya olan etkisi. Selçuk Üniversitesi Ahmet Keleşoğlu Ĕ̌itim Fakültesi Dergisi, 29, 19-27.

Yılmaz, K. \& Çolak, R. (2012). Sosyal bilgiler öğretiminde kavram haritaları kullanımının öğrencilerin tutum, akademik başarı ve bilgilerinin kalıcılık düzeylerine etkisi. Cumhuriyet International Journal of Education, 1(1), 1-9. 